\title{
Julie Schoenung Joins Journal of Sustainable Metallurgy Editorial Team
}

\section{Lynne Robinson}

\section{member news}

Share the good news about your professional accomplishments in the pages of JOM. Contact Lynne Robinson, Magazine Editor, JOM, at Irobinson@ @ms.org with your information. Please note that only current TMS members can submit items for consideration to Member News.

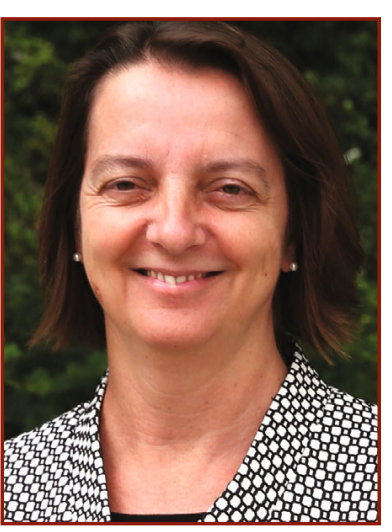

Julie M. Schoenung
As the newly appointed co-editor for the Journal of Sustainable Metallurgy (JSM), Julie M. Schoenung is eager to support the growth of a nascent field that she notes "is vital in our efforts to solve critical materials availability issues, as well as to preserve our natural environment and protect human health."

"JSM provides a venue for papers in which sustainability concepts are explored in great detail and depth, yet consistent with rigorous materials science fundamentals," Schoenung continued. "Other materials journals do not properly showcase the sustainability aspects, and other sustainability journals do not properly showcase the materials fundamentals. In $J S M$, we are able to strike a critical balance between these two, providing a unique platform for researchers to publish their state-of-theart findings in the field of sustainable metallurgy."

Schoenung, a professor of materials science and engineering at the University of California, Irvine, notes that JSM's editorial scope reflects her own efforts to bridge disciplinary boundaries in order to advance materials solutions with impacts across science, public health, and environmental policy. "I completed my graduate studies in materials engineering at the Massachusetts Institute of Technology, with an emphasis on material systems analysis - conducting materials selection and materials processing analyses from a systems perspective, to include economic parameters," she said. Her research portfolio has expanded since to include an array of sustainability topics, "still with a focus to implement a systems approach."

"Of particular interest to me now are issues associated with the design and end-of-life management of electronic and energy-related products, including materials recovery, reuse and recycling," Schoenung commented. "These efforts have continued to grow in parallel to my other research aimed at advancing understanding of materials processingstructure-properties relationships, especially in advanced structural materials, such as nanostructured metals and composites." Beyond her work in the laboratory, Schoenung shares her expertise as a member of California's Green Ribbon Science Panel, charged with advancing the state's Green Chemistry Initiative and Safer Consumer Products Law. She also serves as vice chair for NSF International's Joint Committee on Sustainability Leadership Standards for Photovoltaic Modules.

An associate editor with JSM since its launch in 2014, Schoenung joined Bart J. Blanpain, KU Leuven, Belgium, and Shinya Kitamura, Tohoku University, Japan, as a co-editor on October 1, 2016 to replace Diran Apelian, Worcester Polytechnic Institute, United States, at the conclusion of his term as co-editor. Yiannis Pontikes, KU Leuven, Belgium continues to serve as $J S M$ 's managing editor.

"This opportunity requires a strong commitment to the vision for the journal, and even more so to advancing the field of study. I am committed to both," Schoenung said. "The papers published in $J S M$ are based on strong materials fundamentals, yet they address real-world 
sustainability issues."

Schoenung says she is looking to expand the scope of experimental investigations on materials recovery, reuse and recycling that is currently reported in JSM. "I am also interested in seeing the journal expand to publish papers that highlight the economic and public health benefits of sustainable metallurgy," she said. "In order for sustainable metallurgy to continue to expand and grow as a discipline, the inherent benefit to society must be made apparent, and JSM is an ideal venue to convey these aspects in a rigorous, science based way, along with the more traditional material aspects of the field."

\section{Leonard Harris Receives Hoover Medal}

Congratulations to Leonard Harris, a TMS member since 1983, who has been selected as the 2016 recipient of the prestigious Hoover Medal Award. The Hoover Medal was established to recognize "outstanding extra-career services to humanity" and is administered jointly by American Institute of Chemical Engineers, American Institute of Mining, Metallurgical, and Petroleum Engineers, American Society of Civil Engineers, Institute of Electrical and Electronics Engineers, and American Society of Mechanical Engineers. It is named for Herbert Hoover, the 31st President of the
United States and first medal recipient, who was an engineer by profession.

Harris is being recognized for his tireless efforts to improve community conditions, particularly in the Yanacocha region of Peru, leading to more humane living environments and enhanced futures for thousands of underprivileged children. Harris is currently an industry consultant and has made significant contributions to mining operations throughout the world during his long and distinguished career that included serving as president/general manager of Newmont Peru Limited.

\section{Angus Rockett Heads Department}

Angus Rockett is the new head of the George S. Ansell Department of Metallurgical and Materials Engineering at the Colorado School of Mines. He assumed the post in fall 2016, after serving as a professor of materials science at the University of Illinois since 1987. His research interests include photovoltaics; growth and analysis of thin films; modeling of materials, especially semiconductors; and microelectromechanical systems.

\section{Progress on TMS Materials Data Infrastructure Study}

A workshop hosted at TMS headquarters on November 17 and 18 focused on clarifying challenges and refining nearterm recommendations in the development of a robust materials data infrastructure. Participating in the session were members of the volunteer TMS study team charged

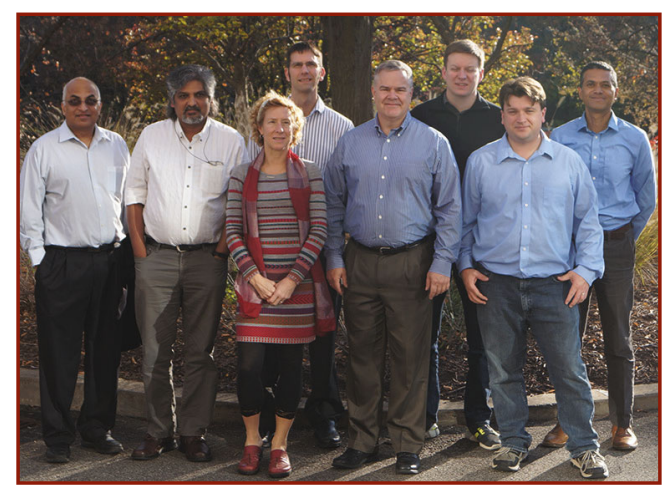

with developing and disseminating, Materials Data Infrastructure: Enabling Storage and Sharing of Data in the Materials Community. The outcomes of the November workshop, as well as other work by the team, will be incorporated into the final study document, set to be released at the 4th World Congress on Integrated Computational Materials Engineering, May 21-25, 2017 in Ypsilanti, Michigan. Pictured between work sessions during the workshop are (from left to right) Surya Kalidindi, Apurva Mehta, Catherine Brinson, Jonathan Petters, Charles Ward (study team chair), Brian Puchala, Zachary Trautt, and Vasisht Venkatesh.

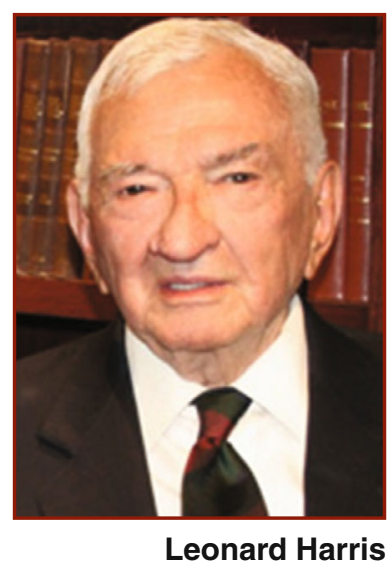

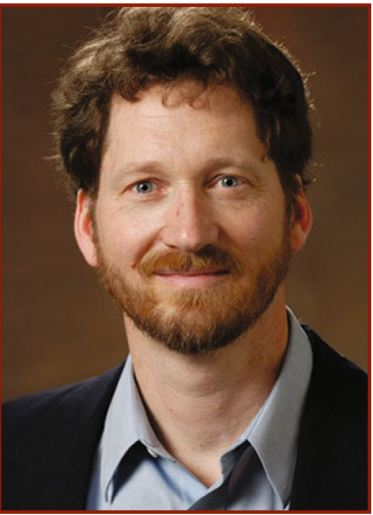

Angus Rockett

\section{Member Publication News}

Shahrooz Nafisi, University of Alberta, published Semi-Solid Process of Aluminum Alloys in the fall of 2016.

Neale Neelameggham, IND LLC, received the 2016 Nanomaterials and Energy Prize from the Institution of Civil Engineers, London, for his paper, "Twenty-first Century Global Anthropogenic Warming Convective Model." 